\title{
Covid-19: An Opportunity to Revive SAARC
}

\author{
Toolika Rani \\ Squadron Leader (Retd.), Research Scholar, \\ BabasahebBhimraoAmbedkar University,Lucknow. \\ Email: tulich83@gmail.com
}

\begin{abstract}
South Asia is a region of immense potential given its abundance of natural resources, young demography, and historical and cultural cohesiveness. However, the colonial legacy and resultant bilateral issues have prevented cooperation to the extent to foster a collective growth. SAARC was conceived with the idea of tiding over these issues and forging cooperation to fight the common challenges of poverty, and infrastructural inadequacy, etc., but the use of terrorism as a state policy to destabilize neighbors resulted in halting of whatever little progress was achieved in SAARC. Due to internal complications, it stands to be the most underutilized regional organization. However, India's initiative to revive it in the face of Covid-19 has raised hopes. The initiation of collective efforts to fight the pandemic has reiterated the significance of SAARC. The paper delves into the promise that the recent move holds, the necessity of a strengthened SAARC, India's role in infusing life in it, and the efforts needed to sustain the much desired regional cooperation, given the wave against globalization and shifting focus to regionalism.
\end{abstract}

Keywords: SAARC, Cooperation, Challenges, Hope, Covid-19, Regional

Reference to this paper should be made as follows:

Received: 05.05.2020

Approved: 07.08.2020

Toolika Rani

COVID-19: AN OPPORTUNITY TO REVIVE SAARC

RJPSSs 2020, Vol. XLVI, No. 1, pp. 118-125

Article No.14

Online available at:

http://rjpsss.anubooks.com/ https://doi.org/10.31995/

rjpsss.2020v46i01.13 
RJPSSs, Vol. XLVI No.1, June 2020 ISSN: (P)0048-7325 (e) 2454-7026 Impact Factor 7.821 (SJIF)

https://doi.org/10.31995/rjpsss.2020v46i01.13

\section{Introduction}

"Geography has made us neighbors. History has made us friends. Economics has made us partners, and necessity has made us allies. Those whom God has so joined together, let no man put asunder."

- John F. Kennedy

Shared borders, similar cultures, combined heritage, common problems, and the same aspirations are what defines South Asia. With these characteristics in mind, South Asian Association for Regional Cooperation (SAARC) was established in 1985 to enable broader regional cooperation in the quest of development for the nations striving to come out of the shadows of their colonial legacies and aspiring to build their future together. However, unlike the other regional organizations such as European Union and ASEAN, which are considered largely successful in achieving their aims, SAARC despite having all the potential, is a study in contrast where bilateral issues, concerns, and mistrust have prevented the smooth functioning of the organization. Although the aim was to promote political, social, and economic integration of the region which has a large poor population of the world, due to the inner contradictions it is still unfulfilled and mistrust has deepened with time. Except for India, most of the member countries are small in size and India's geographical prominence seems to weigh in the dealings. In 2016, when Indian military forces in Uri were attacked by terrorists from across the border, the summit scheduled to be held in Islamabad was boycotted first by India and then by Bhutan, Afghanistan, and Bangladesh. No SAARC summit has been held after that. Since a deadlock seems to have reached in SAARC, many called it a redundant organization, with no hope for the South Asian region. However, the outbreak of Covid-19 has called for emergency measures across the world and India has taken the lead to initiate a dialogue within SAARC to fight the pandemic collectively.

\section{India's Initiative and Response}

As most major countries are busy firefighting within their borders, regional cooperation has taken a back seat. SAARC-that many thoughts were moribund and beyond any scope of revival, meanwhile, has provided some glimmer of hope with India's successful attempt at bringing the eight countries together through Prime Minister Narendra Modi's innovative idea to hold a video conference between the SAARC leaders. Although health infrastructure and capacity are not an asset of most SAARC nations, it is a commendable idea from India to use this unrivaled global crisis as an opportunity to revive regional cooperation through a mechanism whose obituary has been written multiple times over. ${ }^{1}$ 
COVID-19: AN OPPORTUNITY TO REVIVE SAARC

Toolika Rani

PM Narendra Modi surprised many when on March 13 he took to Twitter to propose that leaders from the South Asian Association for Regional Cooperation (SAARC) nations meet via video conferencing to "chalk out a strong strategy to fight Coronavirus." Within a couple of hours, positive responses started pouring in from the leaders of South Asian nations. The tweet was an important, but rather a rare reference to SAARC by the PM in last year. ${ }^{2}$ And the initiative was received in a positive sense by the member countries and foreign policy experts.

In an interview with The Hindu, Major General Abdur Rashid (retd), Head of Institute of Conflict Law and Development Studies in Dhaka said, "There are certainly many commonalities (among these nations) regarding threats and perceptions of threat. Such an initiative will always be welcome. This came as a bolt from the blue since everyone thought SAARC is now in the coffin. But once the meeting was initiated by Mr. Modi, it was welcomed. The people of Bangladesh have also shown a positive attitude. Besides, there is concern about the problem in all these countries. We can talk and keep moving ahead. This will reduce tension and create robust cooperation."

Qamar Agha, a regional affairs commentator from Delhi further elaborated upon the significance of collaboration through SAARC, "The region is integrated culturally and historically. There have been migrations for centuries within the region and we have always been cooperating with each other. It was after British rule that the visa passport regime was introduced. After SAARC, we thought cooperation would develop. It was, in fact, developing. We have common problems: not just Covid-19 but other enormous problems including water sharing and poverty. If we come together, that will once again lead to cooperation."

\section{UPDATED}

MARCH 20, 2020 13:05 IST However seeing the past record of obstruction by Pakistan in the smooth functioning of SAARC, there are apprehensions that the revival may not last long after the COVID crisis. While the deadly virus, which is now a global pandemic, did bring back the term SAARC, this focus is merely issue-based and, in all probability, will not translate into the revival of the organization itself. Pakistan's cold response to the proposal and its decision to send Dr. Zafar Mirza, the Special Assistant to the Prime Minister on Health, to participate in the conference whereas all other member countries were represented by their heads of state, only proves that the India-Pakistan rivalry will continue to hold SAARC to its current inconsequential levels. During the video conference, despite the conference's stated focus being battling the coronavirus, 
RJPSSs, Vol. XLVI No.1, June 2020 ISSN: (P)0048-7325 (e) 2454-7026 Impact Factor 7.821 (SJIF)

https://doi.org/10.31995/rjpsss.2020v46i01.13

Pakistan raised the issue of Kashmir, once again proving that the SAARC process will remain hostage to debates over Kashmir and cross-border terrorism. ${ }^{5}$

For now, the movie is well-timed, well-intentioned, and presents a ray of hope.

\section{Forging Regional Cooperation against a Common Enemy}

The virtual meeting emphasized on assessing the current situation and aimed at identifying areas of cooperation to control the spread of the virus and limit its economic impact. PM Modi said, "We can respond best by coming together, not growing apart, collaboration, not confusion, preparation not panic." $6 \mathrm{He}$ initiated to set up the SAARC joint emergency relief fund and donated \$10 million. Presently, a total of around $\$ 21$ million has been kept aside to help the SAARC countries to deal with COVID-19, however, Pakistan emphasized that the fund should be dealt with in the bloc's framework. A dedicated website was created by SAARC Disaster Management Center, Gandhinagar, to facilitate the interactions of SAARC health and trade officials to fight the pandemic at the regional level. On 26 March, India hosted another conference with senior health officials of all SAARC countries and agreed to share online training tools for emergency responders and to set up a surveillance platform to trace and handle virus outbreaks. ${ }^{6}$ India has used its SAARC Covid-19 Emergency Fund to send drugs, medical supplies and machines to Afghanistan, Bhutan, Bangladesh, Nepal, Maldives, and Sri Lanka. This amount of $\$ 1.7$ million does not include the transportation of the relief commodities, which has, in some sectors, translated into 2-3 times the value of the relief material as New Delhi chartered flights to quickly reach the material to their destination. ${ }^{7}$

A Diplomatic Gesture India has taken a diplomatic lead by triggering the revival of SAARC. The move shows a continuity and a progress both on India's front. India has been consistent in its emphasis on neighborhood cooperation. And the recent move is in line with India's "Neighborhood First Policy" which was also manifested in the invitation to the SAARC leaders and BIMSTEC leaders during PM Modi's swearing-in ceremonies in 2014 and 2019 respectively. India had also proposed to launch a SAARC satellite which, after Pakistan refused to participate, was renamed as South Asian Satellite, and was India's goodwill gesture towards its neighbors by sharing its free services. The element of progress in India's foreign policy in terms of SAARC can be traced by the fact that it opted to rise above bilateral issues and took a step forward to forge cooperation in the larger interest of the region and humanity. This shows a marked maturation by transcending smaller irritants to achieve a broader goal. 
COVID-19: AN OPPORTUNITY TO REVIVE SAARC

Toolika Rani

The meet was important from the perspective that it is a crisis turned opportunity by bringing together countries of the region for the first high-level SAARC meet since 2014 by providing directional leadership with health diplomacy as its core objective. Even when a global crisis looms large, India has depicted that the SAARC spirit should be sustained and the organizational platform can be used to foster regional cooperation. ${ }^{8}$

Realigning the Focus The India-Pakistan rivalry had always plagued the working of SAARC and paralyzed it since its inception. After the stalemate post-Uri in 2016, countries had started looking beyond SAARC for building relations with organizations elsewhere. India itself had deliberately shifted focus towards BIMSTEC (Bay of Bengal Initiative on Technological and Economic Cooperation) which includes along with some SAARC members two southeast Asian nations Thailand and Myanmar. But as the Covid-19 pandemic grew, the SAARC countries have tried to sideline differences to strengthen their partnership. The recent move is a signal that other regional co-operations such as BIMSTEC are not a substitute to SAARC, nor their growing popularity makes SAARC redundant. They are rather additions in the field of diplomacy and cooperation. SAARC has its own relevance as it possesses a uniquely South Asian character, and therefore is significant in tackling challenges in South Asia, thus a prudence to sustain it.

\section{Counter to China's Growing Footprint in South Asia}

Most of the South Asian nations need development assistance and taking advantage of the same, China had been trying to trap them in debt trap under the garb of infrastructural project loans. The discontent against the same was visible in many nations. Even during the present crisis, despite being surrounded by controversy regarding the origin and intent of Covid-19, China has been trying hard to spread the dragon across the globe by sending medical supplies and other aids. However, this time, the world attitude towards China is of mistrust while India has emerged as a goodwill ambassador. Incidentally, the outbreak of the virus may give India time to rejuvenate its ties with SAARC and attempt to get back its central stature as a reliable and amicable partner. ${ }^{9}$

Modi's move can be seen as a masterstroke to assert India's leadership in the South Asian region. India is also pushing for more clout as the world's largest democracy. Recently, Modi's campaign to portray India as a rising power seemed to be ticking along amid China's multi-billion dollar Belt and Road Initiative (BRI) and some troubles internally in India. China has built inroads in almost every country in the region and promises investments as a part of the BRI, a 21st century Marshall 
RJPSSs, Vol. XLVI No.1, June 2020 ISSN: (P)0048-7325 (e) 2454-7026 Impact Factor 7.821 (SJIF)

https://doi.org/10.31995/rjpsss.2020v46i01.13

Plan to connect Asia, Africa, and Europe. Various countries have pledged their official support to the project, which is part of China's bid for global dominance. So Modi's move may also have the intention to maintain India's leadership role amid China's ambitions. ${ }^{10}$

\section{Longevity and Sustainability}

While there is no doubt that the initiative taken by India has infused reinvigorating air into the organization gasping for breath, it would be naïve to assume that the choked wheels have been oiled enough to move normally and freely. The past record of SAARC and the current geopolitical dynamics in the region suggest that observers should be careful of reading more into this humanitarian effort than the present reality calls for. India, which shares permeable borders with multiple SAARC member states, may find it in its own national security interests to play a leading role in bringing members to the table to synergize response efforts to COVID19. ${ }^{11}$

The video conference held on March 15 stuck strictly to the operational measures, suggestions, and details of dealing with the virus, with the impact of COVID-19 already catching up with the region, particularly the smaller states which are more vulnerable to economic shocks, primarily because of tourism-dependent economies. Announcement regarding the creation of the Covid-19 Emergency Fund was made but no substantial suggestions or comments were made about the longterm future of the organization itself.

With India's leadership in SAARC constantly challenged by Pakistan, the lack of significant results due to structural barriers, and India's increased interest in other sub-regional groupings driven by China's increasing engagement with South Asian as well as Southeast Asian states, India finds little incentive to spend efforts on reviving SAARC as an organization. While extraordinary situations like the current outbreak can lead to issue-based cooperation, the temporary concurrence is not enough to resolve the long-standing structural and political deficiencies that have kept SAARC from being an effective platform for regional cooperation. ${ }^{12}$

\section{Conclusion}

Though the existence of an organization like SAARC is expected and desirable in a region so well connected through history, geographical proximity, and shared past, some long-pending festering bilateral issues had sapped its vitality. SAARC seemed to have lost its significance as India gave precedence to other regional organizations like BIMSTEC. But during Covid-19, India has acted like a mature and responsible state and a reliable regional power by extending support to its neighbors 
COVID-19: AN OPPORTUNITY TO REVIVE SAARC

Toolika Rani

through the pooling of resources under the banner of SAARC. This sprouting again to the life of this organization may prove to be a stepping stone in its revival.

The tragedy of Covid-19 may provide an opportunity for India to demonstrate its compassionate face to secure a region at peace with itself. ${ }^{13}$ It is in continuation with India's constant support to its neighbor during natural/ man-made calamities. Attempts to revive SAARC is another chapter added in India's consistent efforts to strive for a stable and safe neighborhood, working collectively towards development and growth. It reflects the deepening of India's foreign policy objectives by embracing a larger perspective of a connected South Asia. However, the materialization of the dream of New South Asia requires more diplomatic and political will.

Interestingly, Pakistan's less friendly responses have not deterred India from continuing its engagement. ${ }^{14}$ It has opted to overlook the attempts by Pakistan to raise the Kashmir issue even during the meeting called for making a plan to fight Covid-19. By refusing to engage in divergent actions and keeping its focus on strengthening multilateral cooperation, India has reiterated its commitment to work together for the larger good. However, only if the present bonhomie continues and the members make concerted efforts to sustain it, the future of SAARC may look different than it seemed erstwhile. If a crisis succeeds in nations coming together for the survival of humanity and later its development, coexistence, and collective prosperity, despite political differences, it would certainly be an example of good diplomacy.

\section{References}

1. Dr. Mishra Vivek, SAARC's Resurrection: Leadership in the Time of COVID-19, Indian Council of World Affairs, Sapru House, New Delhi, 01 April 2020.

2. GambhirMohak, Covid-19: Can it revive SAARC? South Asian Voices, Regional Affairs March 20, 2020, Retrieved on 14 May 2020, 1330 IST. https:// southasianvoices.org/covid-19-can-it-revive-saarc/

3. BhattacharjeeKallol, Will Modi's COVID-19 fund initiative revive SAARC? The Hindu, March 20, 2020, 00:15 IST, https://www.thehindu.com/opinion/op-ed/will-modiscovid-19-fund-initiative-revive-saarc/article31111318.ece

4. BhattacharjeeKallol, Will Modi's COVID-19 fund initiative revive SAARC? The Hindu, March 20, 2020, 00:15 IST, https://www.thehindu.com/opinion/op-ed/will-modiscovid-19-fund-initiative-revive-saarc/article31111318.ece

5. GambhirMohak, Covid-19: Can it revive SAARC? South Asian Voices, Regional Affairs March 20, 2020, Retrieved on 14 May 2020, 1320 IST. https:// southasianvoices.org/covid-19-can-it-revive-saarc/ 
RJPSSs, Vol. XLVI No.1, June 2020 ISSN: (P)0048-7325 (e) 2454-7026 Impact Factor 7.821 (SJIF) https://doi.org/10.31995/rjpsss.2020v46i01.13

6. Bali Sukanya, India's Cooperation With SAARC During COVID-19, Extraordinary and Plenipotentiary Diplomatist, 28 April, 2020, 12.00, retrieved on 14 May 2020 at $1322 \mathrm{hrs}$ IST,

http:/diplomatist.com/2020/04/28/indias-cooperation-with-saarc-during-covid-19/

7. GuptaShishir, India spends $\$ 1.7$ million from Saarc Covid-19 Fund, Imran Khan is again AWOL, Hindustan Times, 17-04-2020, Retrieved on 14 May 2020, 1325 hrs IST, https://www.msn.com/en-in/news/newsindia/india-spends-dollar17-millionfrom-saarc-covid-19-fund-imran-khan-is-again-awol/ar-BB12MIqK

8. Dr. Mishra Vivek, SAARC's Resurrection: Leadership in the Time of COVID-19, Indian Council of World Affairs, Sapru House, New Delhi, 01 April 2020

9. Bali Sukanya, India's Cooperation With SAARC During COVID-19, Extraordinary and Plenipotentiary Diplomatist, 28 April, 2020, 12.00, retrieved on 14 May 2020 at 1322 hrs IST,http://diplomatist.com/2020/04/28/indias-cooperation-with-saarcduring-covid-19/

10. KarkiBrabim, Why Did India Decide to Activate SAARC During the COVID-19 Pandemic? The Diplomat, March 24, 2020, Retrieved on 12 May 2020, 1430 hrs IST,https://thediplomat.com/2020/03/why-did-india-decide-to-activate-saarc-duringthe-covid-19-pandemic/

11. GambhirMohak, Covid-19: Can it revive SAARC? South Asian Voices, Regional Affairs March 20, 2020, https://southasianvoices.org/covid-19-can-it-revive-saarc/

12. GambhirMohak, Covid-19: Can it revive SAARC? South Asian Voices, Regional Affairs March 20, 2020, Retrieved on 14 May 2020, 1330 IST. https:// southasianvoices.org/covid-19-can-it-revive-saarc/

13. Revival of SAARC, Retrieved on 12 May, $1230 \mathrm{hrs} \mathrm{IST,}$ https://www.drishtiias.com/daily-updates/daily-news-editorials/revival-of-saarc 